\title{
Italian Catholicism in the Face of Contemporary Socio-political Challenges. An Attempt to Analyse
}

\begin{abstract}
The analysis of the attitude of Italian citizens to social challenges - political and economic, assessed from the point of view of their own (non)religiousness, is the purpose of this study. Two methods were used during the study. The comparative one, which allows indicating the diversity of views of socio-religious groups, and the statistical one, including the quantitative and qualitative approach.

The implementation of the chosen goal was based on the adoption of research hypotheses confirmed by the collected material. First of all: on many issues, the views of believers are consistent with the opinions of non-believers and distant in relation to the official position of the Church and hierarchy. Secondly, the views of people declaring themselves as believers differ, which proves that religion is not the primary reference for assessing changes within the political system. In the field of research, the change and collapse of the image of a culturally homogenous state can be noticed. The religious homogeneity of Italy does not confirm the growing number of people declaring themselves as non-believers and non-Catholic religionists. This is also not confirmed by the diversity within the group of Catholics who, in the assessment of social phenomena and political events, are inclined to follow non-religious reasons, mainly programs of right-wing parties, often populist and anti-system, which many Italian Catholics support.
\end{abstract}

Key words: religious determinants, religions in Italy, religion and the political system, Catholicism and social phenomena

A lthough political participation might take on religious functions, religion can also be an essential determinant of the impact on current politics, economic decisions or social processes. It performed this function in Italy, especially in relation to Catholicism, which is a dominating religion in this country. This role, mainly after the Second World War, changed along with the following periods resulting from broad social changes: the period of Catholic triumphalism (1945-1958), the new secularisation (1958-1978) and religious pluralism (after 1978) (Pollard, 2008). Currently, although the majority of citizens of the Italian Republic declare their attachment to the Catholic religion, it is becoming more and more subjectively characterised. This becomes noticeable also in the context of current political events and social phenomena, whose assessment is heterogeneous and thus far from the official teaching of the Church.

The analysis of the attitude of Italian citizens towards social challenges - political and economic, assessed from the point of view of their own (non)religiousness, is the purpose of this study. Its implementation is based on the adopted research hypotheses, directly referring to the issues contained in the title. First of all, on many issues, the views of believers are consistent with the opinions of non-believers and distant in relation to the official position of the Church and hierarchy. Secondly: the views of people declaring themselves as believers differ, which proves that religion is not the primary 
reference for assessing changes within the political system. A change is visible in the field of research, which is the right impulse to deal with this matter. The gap between the image of a culturally homogenous state and its real condition becomes evident.

The study was based on a conceptual network, created by the following categories: religious determinants, religions in Italy, the importance of religion for the political system and the influence of Catholics on social phenomena. Two methods have found their application. Firstly, the comparative method, which allows indicating the diversity of views of the socio-religious groups studied. Secondly, the statistical method, including the quantitative and qualitative approach.

\section{Sociodemographic profile}

The research carried out in December 2017 by Centro Studi sulle Nuove Religioni under the Le Religioni in Italia project shows that Christianity is the dominant religion in Italy. $77.3 \%$ of Italians declared it their religion (74.4\% of the Catholic religion, $4.9 \%$ of the non-Catholic religion). $4.5 \%$ described themselves as followers of non-Christian religions, while the remaining $16.2 \%$ were non-believers, agnostics and atheists (Le religioni in Italia, 2018) (Chart 1).

Chart 1. Religious structure of the Italian population (\%)

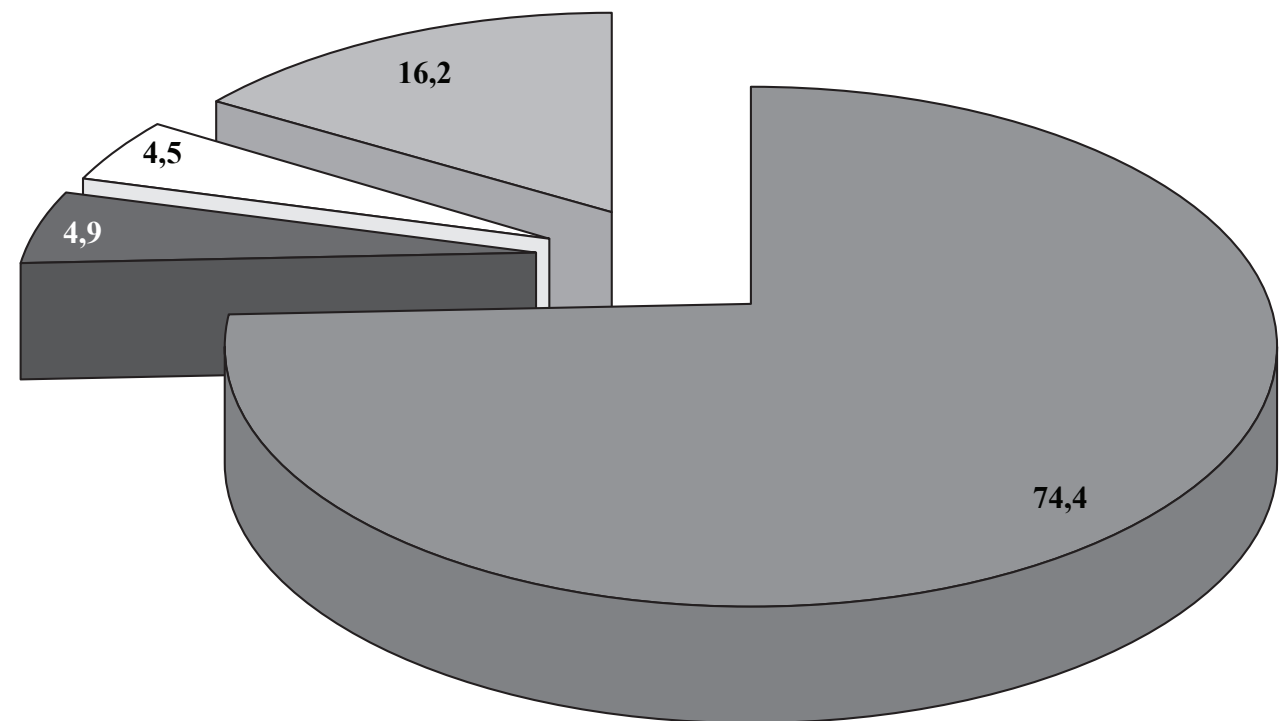

Catholics $\square$ Christians of other denominations $\quad \square$ Non-Christians $\quad \square$ Unaffiliated

Source: Database Pew Research Center.

However, these data are subject to continuous fluctuations. The Pew Research Center demonstrates this, the Pew-Templeton Global Religious Futures project, which presents analyses of religious changes and their impact on societies around the world 
(The Pew-Templeton, 2009-). An essential part of the study are the growth numbers included in it: The Future of World Religions: Population Growth Projections, 2010 2050. They show that in Italy, the decline in the number of believers over forty years will affect only Christians $(-20 \%)$. In the same period, the number of Muslims will more than double $(+150 \%)$, and slightly more - the number of people without any religion (+25\%). ${ }^{1}$ Moreover, in the analysed period, the average age of religious people in Italy will increase by seven years (43-50). Slightly higher growth (by eight years) is forecast for people who do not identify themselves with any religion (40-48). The average age of Christians, the oldest religious group in the country (45-53) will also increase by eight years. Although the average age will also increase among Muslim believers (by four years), they will remain the youngest religious group (32-26) (The Pew-Templeton, 2009-).

These data provide an introduction to the appropriate reflection on the attitude of Catholics - the largest religious group in Italy - to social issues and current political challenges. These issues were devoted to a report prepared by IPSOS Public Affairs entitled I cattolicai tra presenza nel sociale e nuove domande alla politica (November 2017) (I cattolici, 2017). By way of methodological precision, the authors have ranked the test sample according to specific criteria. With regard to three pieces of information (religious faith, participation in services, involvement in the activities of parishes or religious organisations), six groups (segments) were defined: 1) practitioners involved (I praticanti impegnati); 2) Assidous/participants less involved (Gli assidui/partecipanti scarsamente impegnati); 3) Occasional; 4) Non-practicing; 5) Non-believers; 6) Other Religions. ${ }^{2}$

Based on the proposed distinction, a sociodemographic profile has developed which indicates the stratification of the largest religious group in Italy (Table 1). Among the Catholics, the majority are occasional practitioners $(35.6 \%)$ - every tenth one practices regularly and is involved in the local religious environment (11.2\%). Noteworthy is the fact that the second largest and continuously growing group are non-believers $(22.6 \%)$.

${ }^{1}$ According to the Pew Research Center, the number of Christians in Italy will fall by $9,640,000$ over the period 2010-2050. The decline is also forecasted for the followers of Judaism $(-20 \%)$. In turn, the number of followers of Islam will increase by 3,100,000. Other religious communities will also see an increase: Hindus $(+230 \%)$, Buddhists $(+125 \%)$ and followers of natural religions $(+90 \%)$.

2 Each group has been precisely defined. 1) Participants involved (i praticanti impegnati): Catholics who participate in services every week and are involved in the activities of parishes or religious organisations; 2) Assiduous/participants less involved (gli assidui/partecipanti scarsamente impegnati): Catholics who attend weekly services, although not directly involved in the activities of parishes or religious organisations, or participate once or twice a month in services, but maintain some activity in the parish or religious organisations; 3 ) Occasional (i salutari): Catholics who participate less than twice a month in services and are not involved in the activities of the parish or religious organisations; 4) Non-practicing ( $i$ non praticanti): they declare themselves as Catholics, but do not participate in services and are not involved in the activities of the parish or religious organisations; 5) Non-Believers ( $i$ non credenti): they declare themselves as having no religion; 6) Other Religions (credenti in altre religioini): they declare themselves as followers of other religions. 
Sociodemographic profile of groups (\%)

Table 1

\begin{tabular}{|c|c|c|c|c|c|c|}
\hline & $\begin{array}{c}\begin{array}{c}\text { Commit- } \\
\text { ted }\end{array} \\
\end{array}$ & Assiduous & Occasional & $\begin{array}{c}\text { Non-prac- } \\
\text { ticing }\end{array}$ & $\begin{array}{c}\begin{array}{c}\text { Non-be- } \\
\text { lievers }\end{array} \\
\end{array}$ & $\begin{array}{c}\text { Other } \\
\text { Religions }\end{array}$ \\
\hline Total & 11.2 & 15.8 & 35.6 & 11.8 & 22.6 & 3.0 \\
\hline \multicolumn{7}{|c|}{ Sex } \\
\hline Men & 7.9 & 13.1 & 35.2 & 13.1 & 27.7 & 3.0 \\
\hline Women & 14.1 & 18.2 & 36.2 & 10.7 & 18.0 & 2.8 \\
\hline \multicolumn{7}{|c|}{ Age } \\
\hline $18-24$ & 8.1 & 8.2 & 29.8 & 10.4 & 40.1 & 3.4 \\
\hline $25-34$ & 6.4 & 9.6 & 33.8 & 14.8 & 31.7 & 3.7 \\
\hline $35-44$ & 10.3 & 12.5 & 36.9 & 10.7 & 25.4 & 4.2 \\
\hline $45-54$ & 10.7 & 15.6 & 38.1 & 11.8 & 20.3 & 3.5 \\
\hline $55-64$ & 12.1 & 16.8 & 38.0 & 11.8 & 18.9 & 2.4 \\
\hline$>65$ & 15.5 & 23.2 & 34.0 & 11.1 & 14.4 & 1.8 \\
\hline \multicolumn{7}{|c|}{ Qualification } \\
\hline University & 12.9 & 15.5 & 29.7 & 9.4 & 30.0 & 2.5 \\
\hline Secondary & 10.9 & 14.6 & 36.1 & 10.9 & 24.6 & 2.9 \\
\hline Middle & 10.1 & 14.1 & 37.7 & 13.1 & 21.9 & 3.1 \\
\hline Elementary, none & 12.7 & 21.4 & 34.8 & 12.5 & 15.3 & 3.3 \\
\hline \multicolumn{7}{|c|}{ Profession } \\
\hline Entrepreneurs & 8.6 & 14.5 & 32.1 & 11.9 & 30.2 & 2.7 \\
\hline Independents & 10.4 & 15.9 & 35.8 & 11.9 & 22.9 & 3.1 \\
\hline Officials, teachers & 10.3 & 13.6 & 35.8 & 10.8 & 26.6 & 2.9 \\
\hline Workers and similar & 7.0 & 9.6 & 37.2 & 14.4 & 27.0 & 4.8 \\
\hline Unemployed & 8.9 & 10.7 & 37.8 & 13.9 & 24.6 & 4.1 \\
\hline Students & 10.0 & 10.8 & 31.0 & 11.5 & 35.3 & 1.4 \\
\hline Housewives & 15.6 & 21.4 & 40.9 & 9.1 & 10.6 & 2.4 \\
\hline Retirees & 15.4 & 23.5 & 32.8 & 11.8 & 14.7 & 1.8 \\
\hline \multicolumn{7}{|c|}{ Geopolitical areas } \\
\hline North-west & 9.4 & 16.0 & 33.4 & 13.1 & 24.6 & 3.5 \\
\hline Triveneto & 10.5 & 15.2 & 36.2 & 9.9 & 25.5 & 2.7 \\
\hline Red Regions & 8.8 & 12.9 & 31.7 & 14.6 & 28.8 & 3.2 \\
\hline South Centre & 13.1 & 15.8 & 37.1 & 11.5 & 19.6 & 2.9 \\
\hline South and Islands & 13.5 & 17.8 & 39.2 & 9.8 & 17.1 & 2.6 \\
\hline \multicolumn{7}{|c|}{ Wideness of the centres } \\
\hline$<10,000$ & 12.0 & 17.1 & 35.5 & 11.4 & 21.5 & 2.5 \\
\hline $10,000-30,000$ & 10.6 & 15.8 & 37.9 & 11.3 & 21.2 & 3.2 \\
\hline $30,000-100,000$ & 12.1 & 16.6 & 34.7 & 11.9 & 21.6 & 3.1 \\
\hline$>100,000$ & 9.8 & 13.1 & 34.3 & 12.9 & 26.3 & 3.6 \\
\hline \multicolumn{7}{|c|}{ Political autocollocation } \\
\hline Left & 5.7 & 9.2 & 29.8 & 12.8 & 39.0 & 3.5 \\
\hline Centre Left & 11.2 & 16.8 & 35.9 & 11.5 & 22.8 & 1.8 \\
\hline Centre & 18.0 & 20.6 & 35.6 & 9.6 & 14.3 & 1.9 \\
\hline Centre Right & 13.1 & 18.5 & 40.3 & 10.9 & 14.6 & 2.6 \\
\hline Right & 10.7 & 14.2 & 38.8 & 15.1 & 18.6 & 2.6 \\
\hline Not placed & 9.7 & 15.0 & 33.5 & 12.0 & 25.1 & 4.7 \\
\hline
\end{tabular}

Source: Database IPSOS.

The analysis of the level of religiousness proves that the majority of men declared occasional participation in religious practices or unbelief, while women declared irregular 
attendance at services. Regular practices were mainly characterised by people over 55 and occasional - in the range of 45-54 years. The largest group among non-practitioners are people aged 25-34. Primarily young people up to the age of 24 were declared as the non-denominational ones. Among the practitioners, the majority had the elementary education, while the highest percentage of people declaring regular participation in religious practices and religious involvement were people with higher education (12.9\%). At the same time, however, the highest percentage of people who declared themselves as non-believers came from the same segment. In turn, the analysis considering professional qualifications showed that among the people who practiced the highest percentage were housewives and pensioners, the lowest - workers and the unemployed. Attention is drawn to the low involvement of students. It is also a group among which most people declared themselves as non-believers. Religious diversity also has its specific regions. Most of the practitioners lived in the southern, mid-southern and island areas, ${ }^{3}$ the least - the so-called red regions. ${ }^{4}$ Among the inhabitants of these regions and Triveneto, ${ }^{5}$ the most significant number of people with an atheistic or agnostic worldview lived. Practicing and religiously involved people constituted the largest percentage of the population of both small (up to 30,000) and medium $(30,000-100,000)$ cities. From cities over 100,000, the largest group of inhabitants declared themselves as non-believers; it was also there where the highest percentage of people professing a religion other than Catholic lived. The last component of the socio-political profile research were political preferences among people with a certain level of religious commitment. Most practitioners sympathised with views described as centre or centre-right; the left-handed the lowest support in this group. On the other hand, among the non-practicing people were right-wing political sympathies. The Left's greatest support was enjoyed by people who do not identify with any religion.

The mentioned preferences were reflected in the analysis of support for parties and political movements (Table 2).

Table 2

Voting intentions $(\%)^{6}$

\begin{tabular}{|l|c|c|c|c|c|c||}
\hline & Total & Committed & Assiduous & Occasional & $\begin{array}{c}\text { Non- } \\
\text { practicing }\end{array}$ & $\begin{array}{c}\text { Non- } \\
\text { believers }\end{array}$ \\
\hline & 2 & 3 & 4 & 5 & 6 & 7 \\
\hline M5s & 18.4 & 16.5 & 14.1 & 19.6 & 16.7 & 21.1 \\
\hline PD & 16.3 & 19.6 & 19.5 & 15.1 & 15.6 & 16.2 \\
\hline FI & 10.6 & 13.1 & 12.7 & 12.6 & 8.4 & 6.3 \\
\hline
\end{tabular}

${ }^{3}$ Of the 800 Italian islands, 80 are inhabited. The two largest - Sardinia and Sicily - form a separate area, the so-called Island Italy (Italia insulare or Isole). Each of them is a separate administrative region with a special status.

${ }^{4}$ In this way homogeneity of electoral preferences of the inhabitants of four regions was determined: Emilia-Romagna, Toscana, Umbria and Marche.

5 It is a historical land, created today by three regions: Venezia Euganea, Venezia Giulia and Venezia Tridentina.

${ }^{6}$ Movimento 5 stelle (M5s, The Five Star Movement); Partito Democratico (PD, The Democratic Party); Forza Italia (FI, Northem League); Fratelli d'Italia (FdI; Brothers of Italy); Sinistra Italiana (SI, Italian Left); Articolo 1 - Movimento Democratico e Progressista (MDP, Article 1 - Democratic and Progressive Movement); Alternativa Popolare (AP, Popular Alternative). 


\begin{tabular}{|l|c|c|c|r|r|c|}
\hline \multicolumn{1}{|c|}{1} & \multicolumn{1}{|c|}{2} & 3 & 4 & 5 & 6 & 7 \\
\hline LN & 9.8 & 7.0 & 7.8 & 11.1 & 14.2 & 8.5 \\
\hline FdI & 3.3 & 2.5 & 4.5 & 3.8 & 3.8 & 2.0 \\
\hline SI + MDP & 3.1 & 2.3 & 1.7 & 2.3 & 2.7 & 5.8 \\
\hline AP + other center lists & 2.2 & 5.2 & 4.4 & 1.9 & 1.0 & 1.0 \\
\hline Other & 1.4 & 1.9 & 1.5 & 1.0 & 1.0 & 1.7 \\
\hline No vote: absence, no indication & 34.9 & 31.9 & 33.8 & 32.7 & 36.6 & 37.4 \\
\hline
\end{tabular}

Source: Database IPSOS.

The presented data show that the Populist Movement of the Five Stars Beppe Grillo had the largest group of its supporters among non-believers, while the lowest among sporadically practicing. The centre-right Democratic Party, managed by Matteo Renzi during the period of the study, enjoyed the highest support among Catholics who practice irregularly. The group created by Silvio Berlusconi Forza Italia was primarily supported by engaged Catholics, as opposed to non-believers. The right-wing and populist Northern League enjoyed the most significant support among non-practitioners, the smallest among the Catholics involved. In turn, the national-conservative group Italian Brothers, led by Giorgia Maleoni, found a large group of allies among Catholics who do not show religious commitment, while little support from those who declare themselves as non-believers. The joint list of the Italian Left and the Democratic and Progressive Movement led by Nicola Fratoianni and Roberto Speranza was the most popular among those who did not profess any religion. The new centre-right Group Alternative Party, whose head was elected Angelino Alfano, owed its little support mainly to people regularly participating in services. However, the largest group were those who did not vote or were not identifying themselves with any of the political forces of the current party system. In each of the presented segments, the percentage exceeded $30 \%$.

\section{Socio-economic issues}

Another of the thematic blocks of the research conducted by IPSOS were issues related to the economic and political situation of the country. First of all, reference was made to the economic crisis, the current economic situation and its impact on the condition of households (Table 3).

The majority of the respondents negatively assessed the direction in which the state was heading (67\%); only 19\% considered it appropriate - the remaining $14 \%$ did not have an opinion on this subject. Among the fiercest critics were non-practitioners, non-believers and dissenters. On average, every fifth committed Catholic expressed moderate appreciation. Equally critical results described the economic condition of the country, which was negatively assessed by over $80 \%$ of respondents (the highest proportion were non-believers and irregular practitioners), with $22 \%$ of positive opinions (mainly non-Catholics). As for the expected changes in the economic situation in the near future, half of the respondents believed that it would remain unchanged (the dominant percentage was irregularly practicing). The hope for improvement was 
expressed mainly by practicing Catholics, while the fear of the deterioration of the economic situation was betrayed mostly by non-believers. A very high percentage of people in Italian society was concerned about the economic crisis $(75 \%)$. The most worried were people who were occasional practitioners or not practicing at all. By specifying a consistory relative to the «moment» of the crisis, the most numerous groups convinced that the "worst was over" were people who were religiously involved. The strong polarisation within this group is evidenced by the fact that a slightly higher percentage of people claimed that "the worst is yet to come." Among the people willing to describe the situation at the time as the "top of the crisis" were mainly non-practicing.

Table 3

Catholics and economic climate (\%)

\begin{tabular}{|c|c|c|c|c|c|c|c|}
\hline & $\begin{array}{l}\text { Total } \\
\text { cases }\end{array}$ & $\begin{array}{l}\text { Com- } \\
\text { mitted }\end{array}$ & $\begin{array}{l}\text { Assid- } \\
\text { uous }\end{array}$ & $\begin{array}{l}\text { Occa- } \\
\text { sional }\end{array}$ & $\begin{array}{c}\text { Non- } \\
\text { practicing }\end{array}$ & $\begin{array}{l}\text { Non-be- } \\
\text { lievers }\end{array}$ & $\begin{array}{c}\text { Other } \\
\text { Religions }\end{array}$ \\
\hline \multicolumn{8}{|c|}{ Evaluation of the progress of the country } \\
\hline It's going in the right direction & 19 & 24 & 23 & 17 & 20 & 16 & 14 \\
\hline It's going in the wrong direction & 67 & 63 & 58 & 65 & 70 & 70 & 71 \\
\hline Unknown & 14 & 13 & 19 & 18 & 10 & 14 & 15 \\
\hline \multicolumn{8}{|c|}{ Assessment of the state of the country's economy } \\
\hline Very positive & 2 & 3 & 2 & 2 & 1 & 1 & 9 \\
\hline Quite positive & 20 & 23 & 28 & 19 & 18 & 17 & 12 \\
\hline Quite negative & 47 & 39 & 45 & 53 & 50 & 42 & 57 \\
\hline Very negative & 27 & 30 & 21 & 23 & 27 & 35 & 16 \\
\hline Unknown & 4 & 5 & 4 & 3 & 4 & 5 & 6 \\
\hline \multicolumn{8}{|c|}{ Expectations about the evolution of their family economic situation in the immediate future } \\
\hline Expects an improvement & 23 & 36 & 24 & 22 & 25 & 19 & 21 \\
\hline Remain unchanged & 50 & 43 & 47 & 54 & 46 & 50 & 50 \\
\hline Expects a deterioration & 23 & 18 & 25 & 21 & 23 & 25 & 23 \\
\hline Unknown & 4 & 3 & 4 & 3 & 6 & 6 & 6 \\
\hline \multicolumn{8}{|c|}{ Level of concern about the economic crisis } \\
\hline Very worried $(8-10)$ & 45 & 47 & 37 & 48 & 55 & 42 & 39 \\
\hline Enough (6-7) & 30 & 31 & 33 & 32 & 22 & 29 & 29 \\
\hline Little (4-5) & 17 & 13 & 20 & 14 & 16 & 21 & 19 \\
\hline Unconcerned (1-3) & 6 & 5 & 8 & 5 & 6 & 5 & 11 \\
\hline Unknown & 2 & 4 & 2 & 1 & 1 & 3 & 2 \\
\hline \multicolumn{8}{|c|}{ The indication of the perceived "momentum" of the economic crisis } \\
\hline The worst is over & 27 & 35 & 32 & 24 & 24 & 26 & 32 \\
\hline $\begin{array}{l}\text { We are now at the height of the } \\
\text { crisis }\end{array}$ & 29 & 19 & 27 & 31 & 34 & 29 & 19 \\
\hline The worst is yet to come & 34 & 39 & 31 & 36 & 34 & 33 & 34 \\
\hline Unknown & 10 & 7 & 10 & 9 & 8 & 12 & 15 \\
\hline
\end{tabular}

Source: Database IPSOS.

In the next stage of the research, issues related to the most important civic issues were addressed, both at the national and local levels (Table 4). 
Catholics and issues (\%)

\begin{tabular}{|l|c|c|c|c|c|c|} 
Total & Com- & Assid- & Occa- & Non- & Non-be- & Other \\
\hline
\end{tabular}

\begin{tabular}{|l|c|c|c|c|c|c|c|}
\hline & $\begin{array}{c}\text { Total } \\
\text { cases }\end{array}$ & $\begin{array}{c}\text { Com- } \\
\text { mitted }\end{array}$ & $\begin{array}{c}\text { Assid- } \\
\text { uous }\end{array}$ & $\begin{array}{c}\text { Occa- } \\
\text { sional }\end{array}$ & $\begin{array}{c}\text { Non- } \\
\text { practicing }\end{array}$ & $\begin{array}{c}\text { Non-be- } \\
\text { lievers }\end{array}$ & $\begin{array}{c}\text { Other } \\
\text { Religions }\end{array}$ \\
\hline
\end{tabular}

The agenda of citizens' priorities at national level (three possible spontaneous answers - grouping by thematic area)

\begin{tabular}{|l|r|r|r|r|r|r|r|}
\hline Work and employment & 80 & 84 & 81 & 81 & 81 & 79 & 65 \\
\hline Bad functioning of the institutions & 38 & 33 & 31 & 34 & 40 & 45 & 57 \\
\hline Immigration & 34 & 25 & 32 & 38 & 37 & 29 & 51 \\
\hline Welfare and assistance & 28 & 35 & 31 & 32 & 21 & 25 & 15 \\
\hline Safety & 24 & 23 & 24 & 27 & 23 & 20 & 29 \\
\hline Environment and territory & 5 & 5 & 7 & 5 & 3 & 4 & 4 \\
\hline Mobility & 2 & 4 & 2 & 2 & 1 & 2 & 1 \\
\hline
\end{tabular}

The agenda of citizens' priorities at the local level (three possible spontaneous answers - grouping by thematic area)

\begin{tabular}{|l|c|c|c|c|c|c|c|}
\hline Work and employment & 49 & 51 & 49 & 52 & 46 & 49 & 28 \\
\hline Mobility & 30 & 38 & 33 & 30 & 25 & 30 & 25 \\
\hline Safety & 23 & 21 & 28 & 21 & 19 & 22 & 43 \\
\hline Environment and territory & 23 & 17 & 23 & 25 & 23 & 23 & 16 \\
\hline Welfare and assistance & 18 & 20 & 16 & 20 & 17 & 15 & 28 \\
\hline Bad functioning of the institutions & 18 & 16 & 12 & 17 & 24 & 19 & 25 \\
\hline Immigration & 16 & 6 & 22 & 17 & 14 & 16 & 19 \\
\hline
\end{tabular}

Source: Database IPSOS.

With regard to the national level, all groups considered work and employment the most important (80\%), and the least important - mobility (2\%). Non-Catholic denominations indicated the poor functioning of the institution as one of the priorities; they also emphasised the importance of the migration issue. Care and support have been especially crucial for those who regularly participate in services, and for the safety of dissenters. At an even low level, the representatives of all groups were ready to recognise the environment and territory as well as the mobility as mentioned above as a matter of priority.

The priorities agenda at the local level is slightly different. Although employment and employment were also considered the most important issue, with a lower percentage of respondents (49\%), immigration was considered the least important (16\%). Mobility was a serious issue mainly for those who were religiously involved, while for the believers of other religions - security. In turn, non-practitioners pointed to the importance of the environment and territory, while non-Catholics saw the value of care and support. Non-believers paid attention to the issue of the malfunctioning of institutions, whereas non-practitioners - to the migration crisis.

Due to religious preferences, the quality of life in the area of their residence was also assessed $^{7}$ (Table 5). Over a half of the respondents rated it positively (59\%), while the minority $(39 \%)$ was negative.

${ }^{7}$ The weekly "The Economist" developed the «Life-where-to-be Index». Independent variables define it: material well-being as measured, life expectancy at birth, climate, personal security, quality of life, governance, gender equality (Wile, 2013). 
Catholics and quality of life (\%)

\begin{tabular}{|l|c|c|c|c|c|c|c||}
\hline & $\begin{array}{c}\text { Total } \\
\text { cases }\end{array}$ & $\begin{array}{c}\text { Commit- } \\
\text { ted }\end{array}$ & $\begin{array}{c}\text { Assidu- } \\
\text { ous }\end{array}$ & $\begin{array}{c}\text { Occa- } \\
\text { sional }\end{array}$ & $\begin{array}{c}\text { Non- } \\
\text { practicing }\end{array}$ & $\begin{array}{c}\text { Non- } \\
\text { believers }\end{array}$ & $\begin{array}{c}\text { Other } \\
\text { Religions }\end{array}$ \\
\hline \multicolumn{7}{|c||}{ Assessment of the quality of life in your area of residence } \\
\hline Very positive & 17 & 22 & 16 & 16 & 16 & 18 & 11 \\
\hline Quite positive & 42 & 34 & 39 & 44 & 43 & 44 & 36 \\
\hline Quite negative & 23 & 25 & 30 & 20 & 24 & 19 & 47 \\
\hline Very negative & 16 & 16 & 11 & 19 & 15 & 17 & 6 \\
\hline Unknown & 2 & 3 & 4 & 1 & 1 & 2 & 0 \\
\hline \multicolumn{7}{|c|}{ Quality of life trend compared to the past } \\
\hline Improved & 10 & 18 & 10 & 9 & 9 & 9 & 5 \\
\hline Remained unchanged & 41 & 37 & 39 & 37 & 40 & 45 & 64 \\
\hline Worsened & 48 & 45 & 50 & 53 & 49 & 45 & 31 \\
\hline Unknown & 1 & 0 & 1 & 1 & 2 & 1 & 0 \\
\hline
\end{tabular}

Source: Database IPSOS.

Among those who positively assess the quality of life, there are the most regular practitioners and non-believers. The non-Catholic religion sees the quality of life negatively.

In comparison to the past, almost half of the respondents indicate a deterioration in the quality of life (48\%), a little less of them see less significant changes (41\%). Every tenth respondent notices a significant improvement (the highest percentage are those who regularly participate in services). Mainly the believers of other religions described the situation as "remained unchanged." On the other hand, the deterioration of living conditions was emphasised above all by those who believed but were not involved in the activities of religious organisations.

The last issue in this part was the question about the attitude of Catholics to the activities of central and local administration bodies (regional and municipal) (Table 6).

Table 6

Catholics and the work of central and peripheral administrations (\%)

\begin{tabular}{|c|c|c|c|c|c|c||}
\hline \hline Total cases & Committed & Assiduous & Occasional & $\begin{array}{c}\text { Non- } \\
\text { practicing }\end{array}$ & $\begin{array}{c}\text { Non- } \\
\text { believers }\end{array}$ & $\begin{array}{c}\text { Other } \\
\text { Religions }\end{array}$ \\
\hline \multicolumn{7}{|c||}{ Appreciation for the work of the Government } \\
\hline 42 & 43 & 58 & 42 & 47 & 32 & 35 \\
\hline \multicolumn{7}{|c|}{ Appreciation for the work of the Prime Minister } \\
\hline 43 & 44 & 59 & 42 & 46 & 35 & 29 \\
\hline 43 & 48 & 46 & 40 & 42 & 46 & 20 \\
\hline \multicolumn{7}{|c|}{ Appreciation for the work of own regional administration } \\
\hline 46 & 47 & 45 & 47 & 45 & 47 & 26 \\
\hline
\end{tabular}

Source: Database IPSOS.

The actual appreciation for the work of the indicated institutions was expressed by a little more than $40 \%$. Among the ones positively evaluating the activities of the government and its head, the highest percentage were irregularly practicing and active in reli- 
gious groups. The lowest ratings for the government were received from non-believers and the Prime Minister from non-Catholic denominations. Regional administration enjoyed the highest recognition among both believers and non-believers, while the smallest one among non-Catholics. They were also the most critical group in relation to the municipal administration; in turn, religious (Catholics) and non-religious people expressed appreciation for the work of organs of this level.

\section{Current social challenges}

In the last part of the IPSOS report, the views of believers on current social and political issues have been examined. The legalisation of same-sex relationships, the migration crisis, changes in the right to grant citizenship, the European referendum and the phenomenon of populism were recognised as such (Table 7).

Catholics and civil unions (\%)

\begin{tabular}{|l|c|c|c|c|c|c|c|}
\hline & $\begin{array}{c}\text { Total } \\
\text { cases }\end{array}$ & Committed & Assiduous & Occasional & $\begin{array}{c}\text { Non-prac- } \\
\text { ticing }\end{array}$ & $\begin{array}{c}\text { Non- } \\
\text { believers }\end{array}$ & $\begin{array}{c}\text { Other } \\
\text { Religions }\end{array}$ \\
\hline The Parliament approved the civil unions' law by a vote of confidence. As far as you could under- \\
stand, do you approve or disapprove of the new rules adopted?
\end{tabular}

Source: Database IPSOS.

On 5 June 2016, the law regulating civil relationships of persons of the same sex and cohabitation (the so-called legge Cirinnà) ${ }^{8}$ entered into force. By introducing a distinction between them, the act refuses same-sex relationships to adopt children (Regolamentazione, 2016). The ratio of respondents to the adopted law was shared by almost half of Italian society: supporters (37\%) and opponents (41\%). Among the first, the high-

${ }^{8}$ The term comes from the name of Monika Cirinnà, senator of the Democratic Party, promoter of legislative changes in the described area. 
est percentage were non-believers, while among the second - regular practitioners and non-Catholics. A significant group did not take an unambiguous position in this sphere $(22 \%)$.

The next study concerned the extension of the right of adoption to subsequent persons, which in Italy is currently only allowed for couples who are married. Almost a half declared the law in force to be non-changeable (46\%). Somewhat less favoured the extradition of extramarital heterosexual relationships (37\%). On average, every fourth respondent considered it appropriate to grant the right to adoption to single people $(27 \%)$ and homosexual couples (24\%). While in the first case the highest percentage were practicing Catholics, in the remaining three they were non-believers.

The issue, which strongly polarised the political scene and, consequently, also the social mood, was a migration crisis (Dudała, 2018a). This was also reflected in the position adopted by the socio-religious groups under study (Table 8).

Table 8

\section{Catholics and immigration (\%)}

\begin{tabular}{|l|c|c|c|c|c|c|c||}
\hline & Total cases & $\begin{array}{c}\text { Commit- } \\
\text { ted }\end{array}$ & Assiduous & Occasional & $\begin{array}{c}\text { Non-prac- } \\
\text { ticing }\end{array}$ & $\begin{array}{c}\text { Non- } \\
\text { believers }\end{array}$ & $\begin{array}{c}\text { Other } \\
\text { Religions }\end{array}$ \\
\hline \multicolumn{7}{|c|}{ Immigrants are a threat to our culture and our traditions and are not necessary for our future } \\
\hline & 32 & 29 & 30 & 36 & 39 & 28 & 23 \\
\hline \multicolumn{7}{|c|}{ Immigrants are a threat, but they are necessary for our future } \\
\hline & 22 & 16 & 21 & 23 & 26 & 20 & 25 \\
\hline & 22 & 26 & 23 & 21 & 19 & 20 & 29 \\
\hline \multicolumn{7}{|l|}{ Immigrants are not a threat, but they are not necessary for our future } \\
\hline \\
\hline
\end{tabular}

Source: Database IPSOS.

By submitting the views of the respondents to the overall assessment, four proposals for positions were formulated. According to the highest percentage of people $(32 \%)$, immigrants pose a threat to native culture and tradition, and their presence is not necessary for the future of the country. Slightly fewer (22\%) claim that immigrants' presence, although they are a threat, is necessary to prevent a rapid decline in population and resources in Italy. The same number of respondents claim that foreigners, although they do not constitute a threat, however, their presence is not necessary due to the future of the country. Almost as many respondents (23\%) think that immigrants do not pose a threat to Italian culture and tradition, and their presence is necessary for the face of future challenges.

The group that displayed the greatest reluctance towards incoming immigrants were non-practicing or practicing occasionally. On the other hand, practitioners and non-believers did not perceive the threat in their presence, seeing in it also a legitimate interest for the future of the country. 
Another of the questions also covered the migration crisis, and concerned non-governmental organisations dealing with the rescue of immigrants in the Mediterranean (Table 9).

Table 9

Catholics and NGO (\%)

\begin{tabular}{|c|c|c|c|c|c|c|c|}
\hline & $\begin{array}{l}\text { Total } \\
\text { cases }\end{array}$ & $\begin{array}{l}\text { Commit- } \\
\text { ted }\end{array}$ & $\begin{array}{l}\text { Assidu- } \\
\text { ous }\end{array}$ & $\begin{array}{l}\text { Occa- } \\
\text { sional }\end{array}$ & $\begin{array}{l}\text { Non- } \\
\text { practic- } \\
\text { ing }\end{array}$ & $\begin{array}{l}\text { Non-be- } \\
\text { lievers }\end{array}$ & $\begin{array}{l}\text { Other } \\
\text { Religions }\end{array}$ \\
\hline \multicolumn{8}{|c|}{$\begin{array}{c}\text { "I will now read to you some statements concerning non-governmental organisations (NGOs) that } \\
\text { deal with rescuing migrants in the Mediterranean Sea. For each of them tell me if they share it } \\
\text { or not." }\end{array}$} \\
\hline \multicolumn{8}{|c|}{$\begin{array}{c}\text { "The work of humanitarian organisations helps save lives because the authorities alone would } \\
\text { not make it." }\end{array}$} \\
\hline Shares it (votes 6-10) & 55 & 60 & 66 & 47 & 54 & 59 & 52 \\
\hline Not shares it (votes 1-5) & 27 & 25 & 20 & 35 & 25 & 22 & 27 \\
\hline Unknown & 18 & 15 & 14 & 18 & 21 & 19 & 21 \\
\hline \multicolumn{8}{|c|}{ "All humanitarian organisations have an economic interest in saving migrants." } \\
\hline Shares it (votes 6-10) & 60 & 45 & 60 & 67 & 59 & 54 & 78 \\
\hline Not shares it (votes $1-5)$ & 24 & 35 & 27 & 19 & 24 & 27 & 15 \\
\hline Unknown & 16 & 20 & 13 & 14 & 17 & 19 & 7 \\
\hline \multicolumn{8}{|c|}{ "Some humanitarian organisations are certainly in agreement with traffickers." } \\
\hline Shares it (votes 6-10) & 63 & 56 & 62 & 69 & 64 & 56 & 67 \\
\hline Not shares it (votes $1-5$ ) & 22 & 31 & 25 & 18 & 21 & 25 & 15 \\
\hline Unknown & 15 & 13 & 13 & 13 & 15 & 19 & 18 \\
\hline
\end{tabular}

Source: Database IPSOS.

Over half of the respondents (55\%) shared the opinion that the activity of humanitarian organisations helps to save lives and is necessary because state authorities are unable to remedy this alone. Every fourth person (27\%) was of the opposite opinion. Another opinion suggests that all humanitarian organisations saving migrants are guided only by economic interest. $60 \%$ of respondents share it and rejects $24 \%$. The last of these opinions suggests that humanitarian organisations act in cooperation with smugglers. $63 \%$ of respondents supported this opinion, $22 \%$ questioned it.

Among those who appreciate the activities of non-governmental organisations supporting the state in the face of the migration crisis, the highest percentage were Catholics engaged in their communities; the most restrained with the above were non-practicing. For only mercantile motives in rescuing immigrants, organisations were mainly accused by people professing religions other than Catholicism; A critical stance in this matter was presented mainly by committed practicing Catholics. Accusations of cooperation with smugglers towards non-governmental organisations were primarily directed by practicing Catholics and non-Catholic denominations; this view was rejected, though not unequivocally, by those who were religiously involved.

The area of the next study directly referred to the debate on granting Italian citizenship to young immigrants (Ius soli, Ius culturae). Well, during the legislative process there is still a draft bill that grants citizenship to foreigners according to the principles of ius soli and ius cultarae (Modifiche). Concerning the proposed changes, two questions were raised as part of the research (Table 10). 
Catholics and ius soli/ius culturae

\begin{tabular}{|l|c|c|c|c|c|c|c|}
\hline & $\begin{array}{c}\text { Total } \\
\text { cases }\end{array}$ & $\begin{array}{c}\text { Com- } \\
\text { mitted }\end{array}$ & $\begin{array}{c}\text { Assidu- } \\
\text { ous }\end{array}$ & $\begin{array}{c}\text { Occa- } \\
\text { sional }\end{array}$ & $\begin{array}{c}\text { Non- } \\
\text { practicing }\end{array}$ & $\begin{array}{c}\text { Non-be- } \\
\text { lievers }\end{array}$ & $\begin{array}{c}\text { Other } \\
\text { Religions }\end{array}$ \\
\hline $\begin{array}{l}\text { "In general, how much would you agree to extend Italian citizenship to the children of foreign immi- } \\
\text { grants born in our country, with at least one parent having a permanent residence permit in Italy?" }\end{array}$ \\
\hline Agree (votes 6-10) & 47 & 54 & 45 & 43 & 48 & 48 & 57 \\
\hline Disagreement (votes 1-5) & 49 & 35 & 50 & 54 & 48 & 49 & 35 \\
\hline Unknown & 4 & 11 & 5 & 3 & 4 & 3 & 8 \\
\hline $\begin{array}{l}\text { "But how much would it agree to grant Italian citizenship to foreign children or young people who } \\
\text { were born in Italy or arrived there within 12 years and who demonstrate that they have regularly } \\
\text { attended schools in our country for at least five years?" }\end{array}$ \\
\hline Agree (votes 6-10) & 54 & 61 & 52 & 54 & 52 & 57 & 37 \\
\hline Disagreement (votes 1-5) & 43 & 30 & 44 & 46 & 46 & 40 & 57 \\
\hline Unknown & 3 & 9 & 2 & 2 & 2 & 3 & 6 \\
\hline \hline
\end{tabular}

Source: Database IPSOS.

The first question referred to the principle of ius soli and concerned the approval of the right to grant Italian citizenship to children of immigrants born in Italy, of whom at least one has a permanent residence permit in the country. The attitude to the question formulated in this way divided the respondents into two identical groups: supporters $(47 \%)$ and opponents (49\%). The most significant percentage of the first group were non-Catholic religions, in the second case they were mainly "summer" Catholics.

The second question referred to the principle of ius culturae granting Italian citizenship to children of foreigners who were born in Italy or arrived here before the age of 12 and regularly attended an Italian school for at least five years. Most of the respondents expressed their willingness to recognise the above law (54\%) - the opposition expressed less than half (43\%). The attitude of approval was characterised to a large extent by those who were religiously involved, and representatives of non-Catholic denominations demanded the rejection of new records.

Another of the topics present in the public discourse, especially in the context of the statements of the politicians of the present coalition government, was the attitude towards the European Union, of which Italy remains one of the six founding countries. Three issues, formulated in the form of hypotheses, were considered crucial. (Table 11).

Table 11

\section{Catholics and Europe}

\begin{tabular}{|c|c|c|c|c|c|c|c|}
\hline & $\begin{array}{l}\text { Total } \\
\text { cases }\end{array}$ & $\begin{array}{c}\text { Commit- } \\
\text { ted }\end{array}$ & $\begin{array}{c}\begin{array}{c}\text { Assidu- } \\
\text { ous }\end{array} \\
\text { ent }\end{array}$ & $\begin{array}{l}\text { Occa- } \\
\text { sional }\end{array}$ & $\begin{array}{c}\text { Non- } \\
\text { practicing }\end{array}$ & $\begin{array}{c}\text { Non- } \\
\text { believers }\end{array}$ & $\begin{array}{c}\text { Other } \\
\text { Religions }\end{array}$ \\
\hline 1 & 2 & 3 & 4 & 5 & 6 & 7 & 8 \\
\hline \multicolumn{8}{|c|}{ How much confidence do you have in the European Union? } \\
\hline Positive votes $(6-10)$ & 36 & 50 & 41 & 34 & 33 & 34 & 16 \\
\hline Negative votes $(1-5)$ & 59 & 48 & 52 & 62 & 64 & 60 & 56 \\
\hline Unknown & 5 & 2 & 7 & 3 & 4 & 6 & 19 \\
\hline \multicolumn{8}{|c|}{ If a Euro referendum is held in Italy, you would vote... } \\
\hline To exit & 33 & 31 & 31 & 35 & 35 & 32 & 25 \\
\hline To stay & 41 & 43 & 48 & 40 & 38 & 40 & 33 \\
\hline Unknown & 26 & 26 & 21 & 25 & 27 & 28 & 42 \\
\hline
\end{tabular}




\begin{tabular}{|l|c|c|c|c|c|c|c||}
\hline \multicolumn{1}{|c|}{1} & 2 & 3 & 4 & 5 & 6 & 7 & 8 \\
\hline \multicolumn{1}{|c|}{ If in Italy a referendum was held to go out or to stay in the European Union, you would vote... } \\
\hline To exit & 25 & 19 & 21 & 28 & 28 & 26 & 26 \\
\hline To stay & 49 & 63 & 58 & 42 & 50 & 48 & 27 \\
\hline Unknown & 26 & 18 & 19 & 30 & 22 & 26 & 47 \\
\hline
\end{tabular}

Source: Database IPSOS.

When asked about trust in the EU institutions, the vast majority gave a negative answer $(59 \%)$, with a minority of positive votes (36\%). Answers to the other two questions turned out to be more conducive to pro-European sympathies. With regard to the forecast referendum on the eurozone, $41 \%$ were in favour of staying, $33 \%$ for the exit. Also, in the matter of a possible vote on the further membership of Italy in the Union, almost half were in favour of staying (49\%), and every fourth respondent expected an exit (25\%). In both cases, a large number of respondents could not take an unequivocal position (26\%).

The group expressing the greatest confidence in the European Union were practicing and committed Catholics - in contrast to non-believers and non-practitioners. In turn, I prefer to stay in the Euroregion as well as in the structures of the European Union; they were expressed primarily by religiously committed Catholics; non-believers and nonpractitioners mainly made the opposite opinion.

The last phenomenon assessed due to religious commitment was the wave of populism growing in Europe (Dudała, 2018b). It resulted in far-reaching changes in electoral preferences and the transition of power in many countries, including Italy. ${ }^{9}$ In the course of the research, this phenomenon was referred to the party system, legitimisation of power, European Union competences, migration crisis and globalisation, thus creating the so-called Populism Index (Table 12).

Table 12

Catholics and populism

\begin{tabular}{|c|c|c|c|c|c|c|}
\hline Total cases & Committed & Assiduous & Occasional & $\begin{array}{c}\text { Non- } \\
\text { practicing }\end{array}$ & $\begin{array}{c}\text { Non- } \\
\text { believers }\end{array}$ & $\begin{array}{c}\text { Other } \\
\text { Religions }\end{array}$ \\
\hline 1 & 2 & 3 & 4 & 5 & 6 & 7 \\
\hline \multicolumn{7}{|c|}{ According to you, the populist movements that are emerging in different European countries are... } \\
\hline \multicolumn{7}{|c|}{ A threat to democracy $(\%)$} \\
\hline 29 & 34 & 44 & 26 & 25 & 24 & 25 \\
\hline \multicolumn{7}{|c|}{ Parties like others $(\%)$} \\
\hline 18 & 25 & 19 & 18 & 10 & 18 & 25 \\
\hline \multicolumn{7}{|c|}{ Parties that interpret the needs of the people better than others $(\%)$} \\
\hline 31 & 29 & 25 & 29 & 42 & 36 & 13 \\
\hline \multicolumn{7}{|c|}{ Unknown (\%) } \\
\hline 22 & 12 & 12 & 27 & 23 & 22 & 37 \\
\hline \multicolumn{7}{|c|}{ Index of agreement with some statements [scale from 0 (for nothing) to 100 (completely)] } \\
\hline \multicolumn{7}{|c|}{ "The Italian ruling class does not understand the needs and problems of citizens like me" } \\
\hline 85 & 89 & 77 & 84 & 90 & 86 & 91 \\
\hline
\end{tabular}

9 The most spectacular example was the result of the parliamentary elections in Italy (4 March 2018), which resulted in the formation of a government of two populist groups - the Five Star Movement and the Northern League, headed by Giuseppe Conte. 


\begin{tabular}{|c|c|c|c|c|c|c||}
\hline 1 & 2 & 3 & 4 & 5 & 6 & 7 \\
\hline \multicolumn{7}{|c||}{ "Italian interests are not taken into consideration by the European Union" } \\
\hline 77 & 70 & 78 & 79 & 83 & 75 & 58 \\
\hline \multicolumn{7}{|c|}{ "Citizens, not politicians, should make the most important political decisions for Italy" } \\
\hline 67 & 65 & 63 & 68 & 71 & 66 & 60 \\
\hline 59 & 50 & 60 & 62 & 65 & 56 & 47 \\
\hline \multicolumn{7}{|c||}{ "Immigration is a threat to national identity" } \\
\hline 57 & 48 & 60 & 61 & 60 & 52 & 50 \\
\hline 58.5 & "Globalization is a threat to my economic condition" & 47.6 \\
\hline
\end{tabular}

Source: Database IPSOS.

The largest percentage of respondents perceived populist movements as groups that understand the needs of people much better than others (31\%); Non-practitioners and non-believers marked significant participation in this belief. Fewer respondents saw a threat to the functioning of the democratic order in the activities of these parties (29\%); this concern was expressed mainly by engaged Catholics. Almost every fifth respondent rated populist parties as equal groups to the others on the political scene (18\%); this opinion was supported, with little support, by Catholics and people of other religions.

At the next stage (on a scale of 0-100), the ratio to expressions characteristic of populist rhetoric was examined. The first of them indicated that the Italian ruling class did not understand the needs and problems of ordinary citizens. With very high general approval, the largest percentage were non-Catholic faiths. Another opinion suggested that Italian interests are not taken into account by the European Union. To the greatest extent, non-practicing people were in favour of this evaluation, in the smallest one - non-practitioners. The third of the statements suggested that the most important political decisions regarding Italy should be made not by politicians but by citizens. The supporters of this solution were mainly non-practitioners and occasional practitioners. The same two groups confirm the fears of national identity in the light of the incoming immigrants. The last expression concerned globalisation and accompanying threats directly affecting the economic situation of the respondents. The practitioners and non-practitioners were the ones who liked the opinion the most.

The final result of the study was indexation, which allowed to determine the ratio of individual groups to the phenomenon of populism. At a hundred-point scale, the average for all six segments was 58.5. The most vulnerable populist rhetoric turned out to be a group of non-practicing (65.1). An equally high degree of approval for this type of views was presented by people who sporadically practiced (59.2) and non-believers (58.5). In two subsequent groups, the index was slightly below average - among those who regularly practice and are involved in the activities of religious organisations (54.6) and among Catholics characterised by one of these features (55.8). The lowest level of susceptibility to the influence of populist rhetoric was characteristic of people of religion other than Catholic (47.6). 


\section{Conclusions}

A number of studies and published analyses seem to confirm that religion still has a strong influence on the global economy, politics and other areas of life (Micklethwait, Wooldridge, 2009). Hence the thesis of the influential thinkers of the nineteenth century about the loss of the meaning of religion with the advent of industrial society were legitimately subjected to critical analysis (Norris, Inglehart, 2005). Although this does not mean an increase in the number of «nominal» members of traditional communities or organisations, and institutionally-oriented religion seems to remain on the margins of modern society, its significance remains very important. This confirms Thomas Luckmann's thesis about the «invisible religion» and the transformation of religion into religiousness (Luckmann, 1967).

This regularity can also be noticed in the Italian society examined for their religiousness, which is confirmed by the attempt of analysis. The image of Catholicism, the largest religious group in the country, is very diverse in the opinions of believers. For the most part, it is represented by middle-aged women living in the mid-southern regions with an average level of education. The analysis shows the fragmentation of the position regarding issues regarding the assessment of political events and electoral preferences, which proves the validity of the first hypothesis. Thus, in many matters, the views of believers are consistent with the opinions of non-believers and distant in relation to the official position of the Church and hierarchy. The low turnout in practice causes that the subjectification of doctrinal indications, their selective recognition or total negation, is becoming more and more frequent. While the ratio of the official teaching of the Church to the law governing civil unions remains invariably negative, considerable acceptance is seen among lay members of the community. Another example of a similar «disintegration» is the migration crisis. The approving position of the institution and the encouragement of openness towards refugees «collided» with the reluctance and exclusion presented by a significant percentage of Catholics. Thus, according to the second hypothesis, the views of people declaring themselves as believers differ, which proves that religion is not the primary reference for assessing changes within the political system. The image of a culturally homogenous state is broken, in which the social link has so far been religion. The homogeneous Catholic character of Italy, recalled in the literature, requires verification. The growing number of people declaring themselves as non-believers and non-Catholic religionists does not confirm the homogeneous specifics. This is also not confirmed by the diversity within the Catholics themselves who, in assessing social phenomena and political events, are inclined to follow nonreligious reasons contrary to official teaching. Such is the program of right-wing parties, often populist and anti-system, which a large part of Italian Catholics gives their support. All this makes it necessary to define the ratio of Italian Catholicism to contemporary challenges as heterogeneous and requiring further observation and in-depth analysis.

\section{Bibliography}

Dudała R. (2018a), Italian migration policy: Changes and Effects, „Review of Nationalities” [in print].

Dudała R. (2018b), Leadership in the Time of Populism: selected examples of Italian political leaders, „Political Preferences” [in print]. 
I cattolici tra presenza nel sociale e nuove domande alla politica (2017), https://web.archive.org/ web/20180124122738/http://www.acli.it/wp-content/uploads/2017/11/Cattolici-e-politicaanalisi-Ipsos-novembre-2017.pdf, 04.11.2018.

Ius soli, Ius culturae. Un dibattito sulla cittadinznza dei giovani mogranti, Associazione Neodemos 2017, https://www.fieri.it/wp-content/uploads/2017/11/E-book-IUS-SOLI3.pdf, 04.11.2018.

Le religioni in Italia (2018), https://cesnur.com/il-pluralismo-religioso-italiano-nel-contesto-postmoderno-2/, 30.10.2018.

Luckmann T. (1967), The Invisible Religion. The Problem of Religion in Modern Society, Macmillan, New York.

Micklethwait J., Wooldridge A. (2009), God Is Back. How the Global Revival of Faith Is Changing the World, Penguin Press, New York.

Modifiche alla legge 5 febbraio 1992, n. 91 e altre disposizioni in materia di cittadinanza, https://www. senato.it/leg/17/BGT/Schede/Ddliter/46079.htm, 04.11.2018.

Norris P., Inglehart R. (2005), Sacred and Secular. Religion and Politics Worldwide, Cambridge University Press.

Pollard J. (2008), Catholicism in Modern Italy: Religion, Society and Politics, 1861 to the Regolamentazione delle unioni civili tra persone dello stesso sesso e disciplina delle convivenze (2016), no. 76, 20 May 2016, "Gazzetta Ufficiale," no. 118, 21 May 2016.

Present, Routledge, London-New York.

The Pew-Templeton Global Religious Futures Project (2009-), http://www.globalreligiousfutures.org, 30.10.2018.

Wile R. (2013), The 'Best' Countries In The World Have Changed A Lot Since 1988, https://www.businessinsider.com/wond-economist-where-to-be-born-index-2013-1?IR=T, 04.11.2018.

\section{Włoski katolicyzm w obliczu współczesnych wyzwań społeczno-politycznych. Próba analizy}

\section{Streszczenie}

Przedmiotem artykułu jest analiza stosunku obywateli włoskich do wyzwań społecznych - politycznych i ekonomicznych, ocenianych z punktu widzenia własnej (nie) religijności. W toku prowadzonych badań zastosowano dwie metody: porównawczą, który pozwala wykazać różnorodność poglądów grup społeczno-religijnych, a także statystyczną, zakładającą podejście ilościowe i jakościowe.

Realizacja wskazanego celu została oparta na przyjęciu hipotez badawczych potwierdzonych następnie przez zgromadzony materiał. Po pierwsze, w wielu kwestiach poglądy wierzących są zgodne z opiniami niewierzących a odległe w stosunku do oficjalnego stanowiska Kościoła. Po drugie, poglądy ludzi deklarujących się jako wierzący różnią się, co dowodzi, że religia nie jest podstawowym punktem odniesienia dla oceny zmian systemu politycznego. Można przy tym zauważyć odejście od obrazu jednorodnego kulturowo. Przywoływana religijna homogeniczność włoskiego społeczeństwa stoi w opozycji do rosnącej liczby osób deklarujących się jako niewierzący bądź jako wyznawcy religii niekatolickich. Nie potwierdza tego również wewnętrzne zróżnicowanie w grupie katolików, którzy w ocenie zjawisk społecznych i wydarzeń politycznych skłonni są podążać za względami niereligijnymi, głównie programami partii prawicowych, często populistycznych i antysystemowych.

Słowa kluczowe: determinanty religijne; religie we Włoszech; religia i system polityczny; katolicyzm i zjawiska społeczne 
